\title{
Antarctic ozone variability inside the polar vortex estimated from balloon measurements
}

\author{
M. C. Parrondo ${ }^{1}$, M. Gil ${ }^{1}$, M. Yela ${ }^{1}$, B. J. Johnson ${ }^{2}$, and H. A. Ochoa ${ }^{3}$ \\ ${ }^{1}$ Atmospheric Research and Instrumentation Branch, National Institute for Aerospace Technology, Torrejón de Ardoz, Spain \\ ${ }^{2}$ Global Monitoring Division, NOAA Earth System Research Laboratory, Boulder, Colorado, USA \\ ${ }^{3}$ Dirección Nacional del Antártico/Instituto Antártico Argentino (DNA/IAA), Buenos Aires, Argentina
}

Correspondence to: M. C. Parrondo (parrondosc@inta.es)

Received: 22 February 2013 - Published in Atmos. Chem. Phys. Discuss.: 13 June 2013

Revised: 30 October 2013 - Accepted: 20 November 2013 - Published: 9 January 2014

Abstract. Thirteen years of ozone soundings at the Antarctic Belgrano II station $\left(78^{\circ} \mathrm{S}, 34.6^{\circ} \mathrm{W}\right)$ have been analysed to establish a climatology of stratospheric ozone and temperature over the area. The station is inside the polar vortex during the period of development of chemical ozone depletion. Weekly periodic profiles provide a suitable database for seasonal characterization of the evolution of stratospheric ozone, especially valuable during wintertime, when satellites and ground-based instruments based on solar radiation are not available. The work is focused on ozone loss rate variability (August-October) and its recovery (NovemberDecember) at different layers identified according to the severity of ozone loss. The time window selected for the calculations covers the phase of a quasi-linear ozone reduction, around day 220 (mid-August) to day 273 (end of September). Decrease of the total ozone column over Belgrano during spring is highly dependent on the meteorological conditions. Largest depletions (up to 59\%) are reached in coldest years, while warm winters exhibit significantly lower ozone loss $(20 \%)$. It has been found that about $11 \%$ of the total $\mathrm{O}_{3}$ loss, in the layer where maximum depletion occurs, takes place before sunlight has arrived, as a result of transport to Belgrano of air from a somewhat lower latitude, near the edge of the polar vortex, providing evidence of mixing inside the vortex. Spatial homogeneity of the vortex has been examined by comparing Belgrano results with those previously obtained for South Pole station (SPS) for the same altitude range and for $9 \mathrm{yr}$ of overlapping data. Results show more than $25 \%$ higher ozone loss rate at SPS than at Belgrano. The behaviour can be explained taking into account (i) the transport to both stations of air from a somewhat lower latitude, near the edge of the polar vortex, where sunlight reappears sooner, resulting in earlier depletion of ozone, and (ii) the accumulated hours of sunlight, which become much greater at the South Pole after the spring equinox. According to the variability of the ozone hole recovery, a clear connection between the timing of the breakup of the vortex and the monthly ozone content was found. Minimum ozone concentration of $57 \mathrm{DU}$ in the $12-24 \mathrm{~km}$ layer remained in November, when the vortex is more persistent, while in years when the final stratospheric warming took place "very early", mean integrated ozone rose by up to $160-180 \mathrm{DU}$.

\section{Introduction}

The discovery of the Antarctic ozone hole in the mid-1980s (Farman et al., 1985) intensified interest in stratospheric chemistry for a better understanding of the chemical and dynamical processes involved. At present, one of the main goals for the stratospheric ozone community is to detect the expected ozone recovery, helped through the Montreal Protocol for the Protection of the Ozone Layer and its amendments (WMO, 1995, 2007, 2010), which led to the reduction in the abundance of anthropogenic ozone-depleting substances (Weatherhead and Andersen, 2006) and to the complex relationship between ozone depletion/recovery and climate change (Eyring et al., 2010). Beyond the direct consequences caused by the reduction of the ozone layer, such as the increased levels of ultraviolet radiation at the surface (Frederick and Alberts, 1991; McKenzie et al., 1991; Lubin and Jensen, 1995), the impact of the ozone hole goes 
further. Recent studies based on coupled chemistry-climate models have shown that stratospheric ozone affects the whole atmospheric circulation in an unexpected number of ways (Son et al., 2009). For instance, ozone depletion seems to have contributed to increasing the Southern Annular Mode (SAM) index (Thompson and Solomon, 2002; Arblaster and Meehl, 2006), poleward shifting of the westerly jet in midlatitudes and increasing global tropopause height (Santer et al., 2003). Models predict that these changes will probably reverse due to the ozone recovery (Son et al., 2009). Thus, in recent years, great attention has been paid to the timing of ozone recovery. First convincing evidence of the rebound has been recently provided by Salby et al. (2012). Chemistryclimate models are an excellent tool to investigate how the decreasing in atmospheric halogen compounds loading to natural "background" levels will lead to stratospheric ozone recovery in the near future (Austin et al., 2010). Several indexes are commonly used to quantify and study the variability of the Antarctic ozone depletion, including minimum total ozone, ozone hole area (Stolarski et al., 1990; Bodeker et al., 2005) and ozone mass deficit (Uchino et al., 1999; Huck et al., 2007). However, for individual stations, ozone loss rate is used in many studies to assess the degree of the severity of the ozone depletion. Long-term series of ozone loss rate have been used to detect ozone changes as a consequence of a decline in the equivalent effective stratospheric chlorine (EESC) levels. Assuming a linear relationship between ozone loss rate and EESC, Hassler et al. (2011) found that a reduction of the ozone loss rate at South Pole station (SPS hereafter) will be detectable in 2017-2021 period. In recent years, estimates of the ozone loss rate based on different satellite instrumentation (Tilmes et al., 2006; Sonkaew et al., 2013), ground-based instrumentation (Kuttippurath et al., 2010, 2013) and balloon-borne measurements (Hassler et al., 2011; Hoffmann et al., 2009) for the Antarctic region have been published.

The severe destruction of Antarctic ozone is followed by its recovery in summer months. By the end of October or the beginning of November, the polar vortex begins to weaken, causing an exchange of air masses between vortex and extravortex air. When the vortex breaks up, ozone-rich air from outside replaces the ozone hole region and ozone starts its recovery. The rate and the timing of the recovery are influenced by the meteorological conditions of the polar vortex. Several works have analysed the interannual variability of the vortex breakup using different criteria (Waugh et al., 1999; Haigh and Roscoe, 2009; Black and McDaniel, 2007) and have exhibited a trend in the persistence of the Arctic and Antarctic polar vortices.

In the present paper, previous studies of the variability of the ozone loss in the Antarctic region are extended using $13 \mathrm{yr}$ of ozonesonde measurements at Belgrano II, a station located well inside the polar vortex where the ozone hole occurs each year (Parrondo et al., 2007). Results are compared to those at SPS (Hofmann et al., 2009). Interannual evolution of the ozone recovery in November and December has been analysed as well.

This paper is organized into five sections. Following this introduction, Sect. 2 describes the data used for the work. In Sect. 3, the methodology applied for ozone loss rate calculation and the diagnostics of the polar vortex are presented. The main results are shown in Sect. 4, which is further divided into five subsections. Finally, a summary and the main conclusions are given in Sect. 5.

\section{Measurements}

The ozone sounding programme at Belgrano II Antarctic station started in June 1999 as a joint effort between Argentinean Dirección Nacional del Antártico (DNA) and Instituto Nacional de Técnica Aerospacial (INTA). Since then, ozonesondes have been regularly launched at a frequency of 2 profiles per month during summer and autumn months and up to 6-10 profiles in winter and spring months on Wednesdays at 12:00 GMT, whenever possible. Electrochemical concentration cells (ECC) from two manufacturers have been used: SPC-6A (Science Pump Corporation) and ENSCI-Z (En-SCI Corporation). Chemical-sensing solutions for both types of sondes have been prepared following the recommendations of each manufacturer. The standard cathode solution used was $1 \% \mathrm{KI}$ buffered for SPC6A (Komhyr et al., 1995) and 0.5\% KI buffered for ENSCIZ (EN-SCI Corporation, 1996). The sonde was interfaced to a meteorological radiosonde from Väisala for pressure, temperature and humidity data. The entire system is flown on a TOTEX balloon (TX-1200) filled with helium. Balloons were dip-oil-treated to reduce the occurrence of low burst height under very cold conditions, the mean burst altitude under normal conditions being around $30 \mathrm{~km}$. A TSC-1 ozonizer/test unit (manufactured by Science Pump Corporation) was used for the calibration and preparation of sondes according to the recommendations given by Komhyr (1986). Laboratory studies performed to assess the quality and reliability of ozonesondes show that sondes operated according to standard operating procedures for ECC sondes can yield a precision of 3-5 and 5-10\% accuracy at up to $30 \mathrm{~km}$ altitude (Smit et al., 2007; Deshler et al., 2008; WMO, 2011).

For each sounding, the ratio between total ozone column obtained by an independent nearby instrument and the integrated ozone from the ozonesonde profile plus the residual ozone has been calculated as a quality control parameter (Logan, 1994). Based on the criterion that the ratio should be in the 0.8-1.2 range (maximum allowed discrepancy $20 \%$ ), a total of $2 \%$ of the profiles were rejected. Residual ozone from the balloon burst altitude to the top of the atmosphere has to be estimated. Several methods can be used for this purpose, giving differences of about 10-20 DU (Thompson et al., 2003). In this work residual ozone was calculated assuming a constant mixing ratio above the balloon burst 
altitude if the balloon reaches $17 \mathrm{hPa}$ (Claude et al., 1987). For reference, total ozone data from the Total Ozone Mapping Spectrometer (TOMS) version 8 and the Ozone Monitoring Instrument (OMI) on board the Earth Probe satellite and NASA's EOS-Aura, respectively, as well as total ozone from the Brewer spectrometer installed at Belgrano station have been used.

\section{Methodology}

\subsection{Selection of layers and time window}

Three contiguous layers in the lower stratosphere can be identified as being affected by the ozone depletion. Boundary levels have been selected according to the degree of severity in its maximum phase (October) with respect to the mean "normal" ozone profile (Kuttippurath et al., 2010). Figure 1 displays the mean ozone profiles used for layers selection. We followed Lee at al. (2000) for the selection of the "normal" reference as the mean profile of all available soundings from 15 June to 15 July (blue line in Fig. 1). For the most depleted period, the mean ozone profile was computed from the subset of the minimum profile registered each year (black line). Minimum ozone values are generally observed by the end of September or early October. The three layers identified are the following: layer I extends from the lowest part of the stratosphere, from 12 to $15 \mathrm{~km}$; layer II extends from 15 to $21 \mathrm{~km}$; and layer III from 21 to $24 \mathrm{~km}$. The ozone removal is almost complete in layer II $(95 \pm 2.3 \%)$, whereas in layers I and III only about half of the ozone is destroyed. The degree of ozone loss in each layer agrees with values given by Solomon et al. (2005) and Hofmann et al. (2009) for SPS. The low standard deviations, represented by a blue and gray shaded areas, provide information on the low inter-annual variability in the shape of the maximum depleted ozone profile, as other previous studies have pointed out. These data reassert the low inter-annual variability of the Antarctic ozone loss (Kuttippurath et al., 2010).

The general evolution of ozone loss inside of the polar vortex exhibits a phase of a slow ozone decline, followed by a period of quick ozone destruction. The timing of each phase for a specific station depends on the geographic position with respect to the polar vortex (Kuttippurath et al., 2010). The time window of our study is focused on the period when the ozone decrease is nearly linear in time, and has been determined for each of the layers by the mean ozone evolution for the 1999-2011 data set. A slight delay in the timing for the onset is observed in the lowest layer. In general, the time window extends from day 220 (8 August) to 273 (30 September).

A deep analysis of the ozone loss rate has been performed in the layer II comparing results from Belgrano with the ones obtained by Hofmann et al. (2009). For this study the time

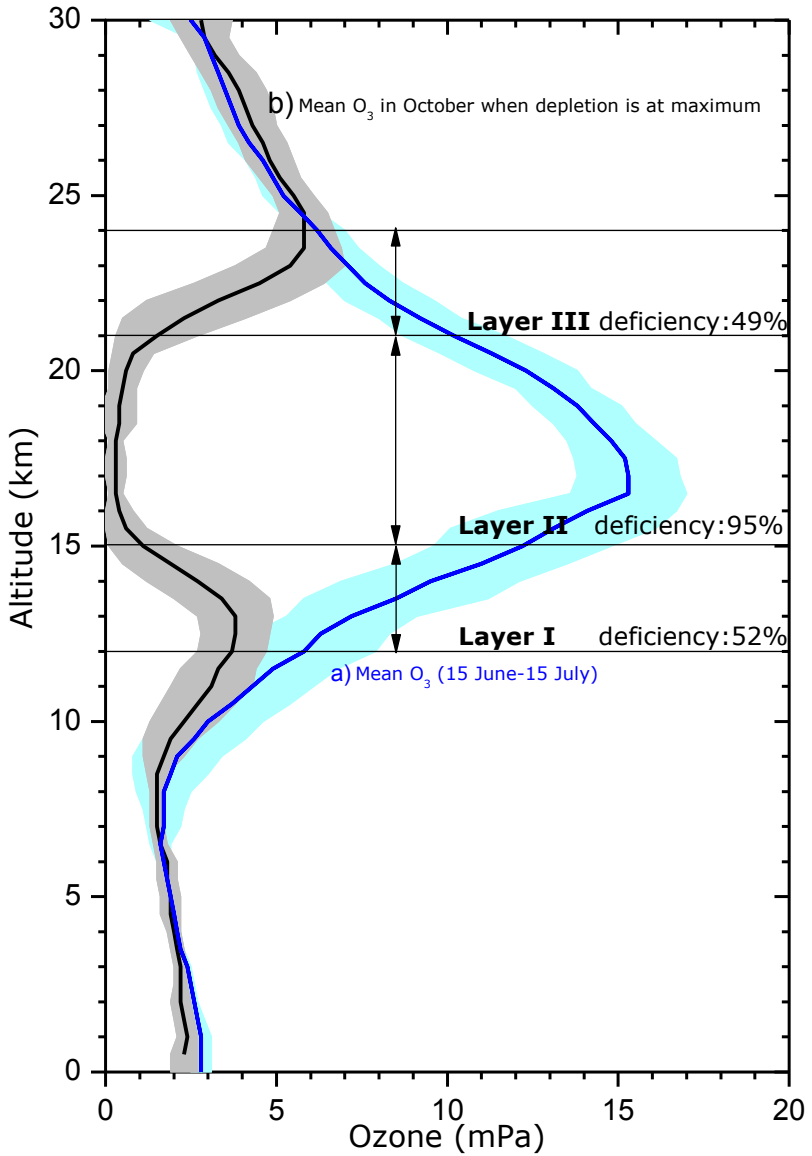

Fig. 1. Mean ozone profiles obtained from the $13 \mathrm{yr}$ data (19992011) of Belgrano station. (a) Winter profile typical of pre-ozonehole conditions for the period 15 June to 15 July (blue line). (b) October-mean profile, when ozone depletion is at maximum depletion (black line). Shaded areas indicate one standard deviation of the monthly means within the $13 \mathrm{yr}$ average. The three layers of study are shown.

window covers the month of September as to follow the same procedure.

\subsection{Ozone loss rates and ozone recovery}

Ozone loss rates have been calculated for each year in a specific common time window for the total ozone column and for each of the three layers defined in Sect. 3.1. In each layer, we calculated the integrated ozone column of all sondes covering the corresponding time window. By fitting these data to a linear regression model, the ozone loss rate is obtained as the slope of the linear regression. A similar procedure has been applied to estimate the ozone recovery rate, the time window in this case being the period from mid-October (day 288 ) to the end of December. 

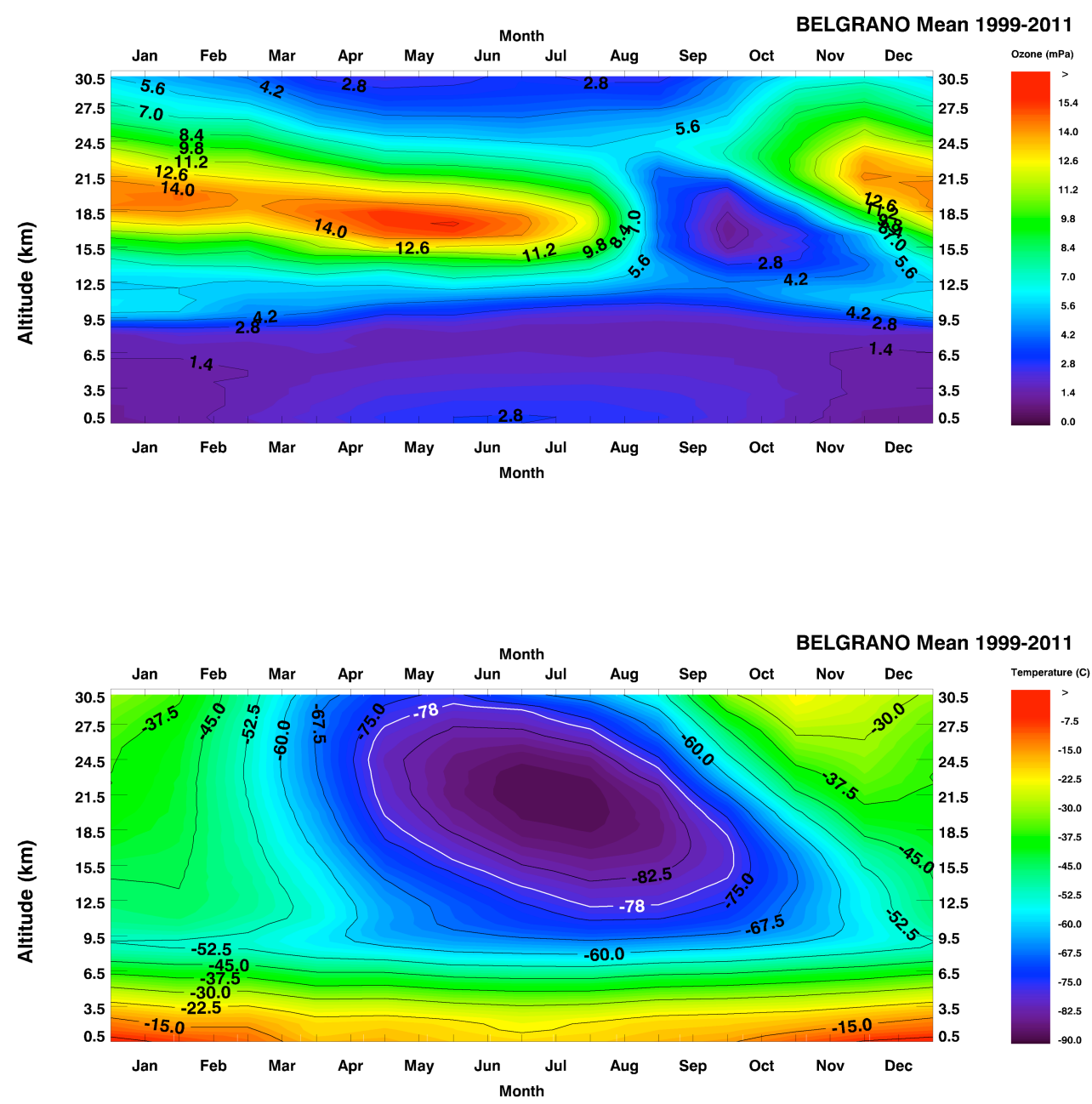

Fig. 2. Time-height cross sections of ozone (upper panel) and temperature (lower panel) over Belgrano obtained from the monthly mean profiles for the period (1999-2011). The isothermal of $-78^{\circ} \mathrm{C}$ is plotted in white, defining approximately the boundaries of time and height where PSC formation is possible.

\subsection{Vortex edge and position of the station with respect to the polar vortex}

The position of the polar vortex and its boundaries has been calculated for each day from 1 May to 31 December using the widely accepted method of Nash et al. (1996). Potential vorticity from European Centre for Medium-Range Weather Forecasts (ECMWF) truncated to T106 horizontal resolution $\left(1.125^{\circ} \times 1.125^{\circ}\right)$ at the isentropic level of $475 \mathrm{~K}$ has been used. The isentropic level of $475 \mathrm{~K}$ has been chosen for the study as it represents a mean level of the low stratosphere where the maximum ozone number density is observed. Each day was classified in three groups according to the position of the station with respect to the polar vortex: inside, outside and at the edge of the polar vortex.

\subsection{Breakup of the polar vortex}

The common criteria used to determine the date of the spring breakdown of the polar vortex are based on the time when the parameters considered for diagnosis of the vortex reach a predetermined threshold. In this work, potential vorticity and zonal winds are used to characterize the behaviour of the polar vortex. The first criterion defines the breakup as the date when the equivalent latitude of potential vorticity at $500 \mathrm{~K}$ for $\mathrm{PV}=46 \mathrm{PVU}\left(1 \mathrm{PVU}=10^{-6} \mathrm{~km}^{2} \mathrm{~s}^{-1} \mathrm{~kg}^{-1}\right)$ is above $80^{\circ}$ (Waugh et al., 1999). The second criterion determines the stratospheric final warming date as the day when the running 5-day average of the zonal-mean wind at $50 \mathrm{hPa}$ and $70^{\circ} \mathrm{S}$ becomes negative and does not change to values higher than $5 \mathrm{~m} \mathrm{~s}^{-1}$ until the next year (Black and McDaniel, 2007). 


\section{Results}

\subsection{Ozone and temperature seasonal evolution}

Figure 2 displays the time-height cross section for ozone and temperature at Belgrano based on climatological monthly mean profiles. In January, ozone reaches a maximum at an altitude of $20 \mathrm{~km}$ and a concentration of $14 \mathrm{mPa}$. From that date onward, the height of the maximum descends at a rate of $22 \mathrm{mday}^{-1}$ from February to May. The lowering in the height of the maximum is partially a consequence of an $\mathrm{O}_{3}$ reduction in the $25-38 \mathrm{~km}$ layer height due to $\mathrm{NO}_{\mathrm{x}}$ catalytic cycles (Osterman et al., 1997; Fahey and Ravishankara, 1999; Crutzen and Brühl, 2001) poleward of $70^{\circ}$ (Cordero and Kawa, 2001) in a season where the meridional transport is small, but is also due to the descent of the downward branch of the Brewer-Dobson circulation. This climatological picture is close to the $3-7 \mathrm{~km}$ of descent over an 8-month period extending from 1 March to 31 October that Rosenfield et al. (1994) found for the years 1987-1992 using National Meteorological Center (NMC) temperatures and a radiation model.

From the ozonesonde record alone it is challenging to detect any evolution during summer in total ozone column due not only to large scattering in integrated data but also because the upper part of the stratosphere is truncated. OMI data (not shown), however, display a clear signature of a slow decline of no more than $0.25-0.4 \mathrm{DU} \mathrm{day}^{-1}$ which is abruptly stopped when the vortex edge passes over the station. Inside the vortex, and before chemical depletion takes place, a slight increase in ozone is attributed to air subsiding by diabatic cooling (Christensen et al., 2005).

The ozone hole phase starts by mid-August with the arrival of solar radiation and proceeds almost simultaneously at all levels. The recovery, on the other hand, starts at upper levels before the maximum depletion takes place, in midOctober, preventing the total ozone column from becoming even lower. The ozone-enriched air resulting from poleward eddy transport (Miyazaki et al., 2005) arrives at the polar region when the vortex edge barrier disappears and propagates downwards. The height of maximum ozone concentration descends at a rate of $38 \mathrm{~m} \mathrm{day}^{-1}$ from October to January. It is worth noting that chemical ozone depletion extends until January in the 12-15 km layer (Sato et al., 2009).

The temperature structure is dominated by the winter radiative cooling, reaching minimum temperatures at $21 \mathrm{~km}$. Height and time of polar stratospheric cloud (PSC) presence defined by the threshold temperature for the existence of nitric acid trihydrate (NAT) (Hanson and Mauersberger, 1988) extends from May to late October with a large vertical extension of over $15 \mathrm{~km}$, covering $58 \%$ of the mid- and lowstratospheric layer $(12-30 \mathrm{~km})$ from May to October. Minimum temperature occurs by the end of July at $21 \mathrm{~km}$. As spring proceeds, heating at upper levels propagates downwards, closely coinciding with ozone increase at a mean rate

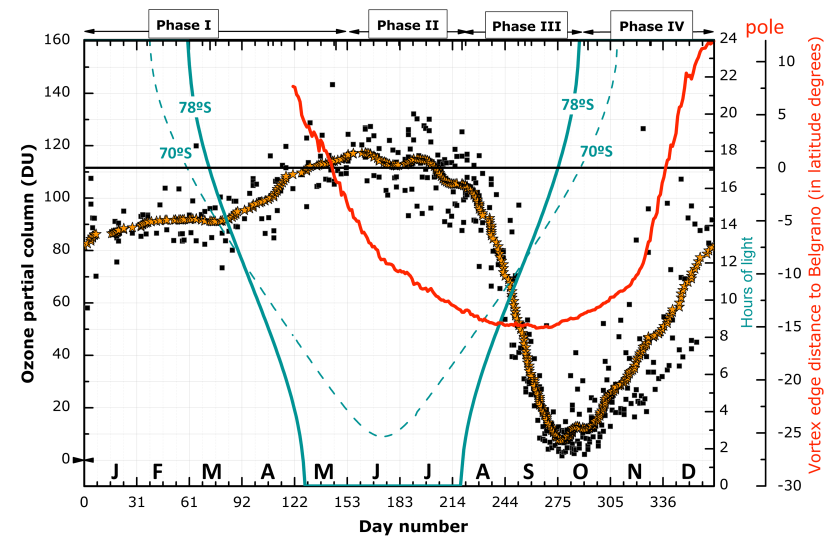

Fig. 3. Seasonal evolution of the 1999-2011 mean ozone in the layer $15-21 \mathrm{~km}$ (30-day running mean as orange stars). Individual data from ozonesondes for $13 \mathrm{yr}$ are shown in black squares. Daily mean distance from the vortex edge to Belgrano in terms of equivalent latitude computed for the same period (red solid line). Negative values mean that Belgrano is inside the vortex. Hours of light at 78 and $70^{\circ} \mathrm{S}$ in the stratosphere $(25 \mathrm{~km})$ are represented by the dashed blue line and thick blue line, respectively.

of about $0.5^{\circ} \mathrm{Cday}^{-1}$. From the beginning of January to March the lower stratosphere is progressively cooling down but remains essentially isothermal in the $12-30 \mathrm{~km}$ layer.

\subsection{Seasonal evolution of ozone in the layer where complete ozone depletion takes place $(15-21 \mathrm{~km})$}

Figure 3 displays a 30-day running mean of ozone partial column over Belgrano in the layer where the maximum depletion takes place $(15-21 \mathrm{~km})$ for all available soundings. Four clear phases can be identified. In phase I, ozone increases from January to mid-June, when annual maximum values are reached. Afterwards, two periods of ozone decrease are observed. In the first one (phase II) the decay is attributed to dilution effects of poor-ozone air from a somewhat lower latitude near the edge of the polar vortex, where ozone loss has already started (Roscoe et al., 1997), providing evidence that low but not negligible mixing takes place between the edge region of the vortex and the core (Roscoe et al., 2012). During this period, the partial column has decreased by almost $11 \%$ with respect to the maximum occurring on day 160. Studies based on backward trajectories have shown how ozone-depleted air from lower-latitude regions of the polar vortex exposed to sunlight and in the presence of PSC could be transported poleward, reducing the ozone content at higher latitudes (Sato et al., 2009). In phase III, a direct chemical depletion evolves almost linearly from day 220 , just after the arrival of sunlight, and onwards. The thick green-blue curve for $78^{\circ} \mathrm{S}$ shows the hours of sunlight at a height of $25 \mathrm{~km}$. Minimum $\mathrm{O}_{3}$ partial column is reached by early October (day number 277), 57 days after the arrival of light at $25 \mathrm{~km}$ altitude. Mean ozone depletion in this phase is 


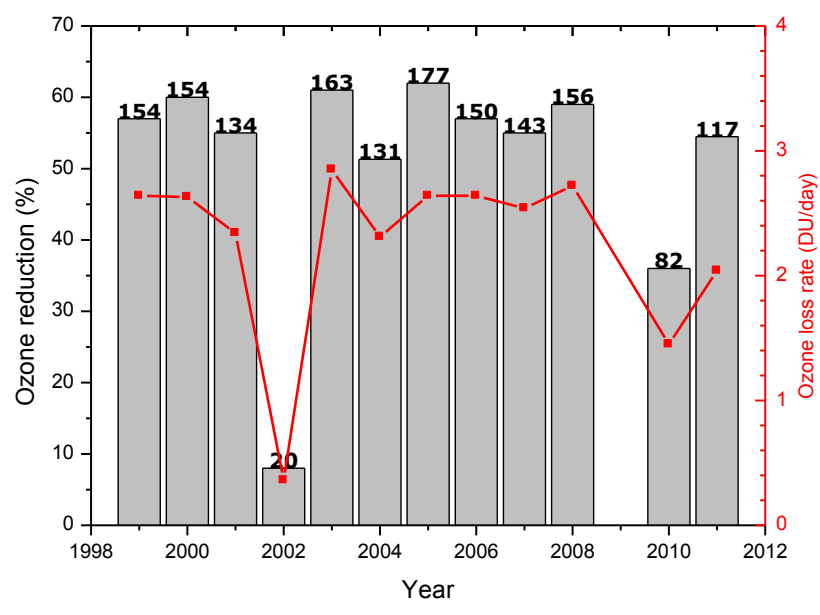

Fig. 4. Time series of ozone loss rate during phase II (red line and right scale) for the total ozone column and ozone reduction with respect to ozone in August in percent (left scale). The total amount of ozone depleted (DU) is shown at the top of the bars. In 2009 not enough sondes reached the minimum altitude to evaluate the total ozone column, so the ozone loss rate for this year is not available.

2.0 DU day ${ }^{-1}$. Typical ozone residual at the end of this phase in this layer is only $5 \%$ of the winter values. After minimum occurrence, the ozone recovery also takes place linearly at a slower rate of $0.78 \mathrm{DU} \mathrm{day}^{-1}$ and, as previously mentioned, is due to a downward propagating refilling from the top of the layer (phase IV). The thick red line represents the daily mean distance from the vortex edge to the station in terms of equivalent latitude at the isentropic level of $475 \mathrm{~K}$ (approximately $18 \mathrm{~km})$. Negative values indicate that the station is inside the vortex. The figure shows that Belgrano is located well inside the vortex at this level from mid-May to early December.

\subsection{Ozone loss rate and variability}

This section is devoted to the analysis of the inter-annual variability of the ozone loss in Belgrano. The ozone loss rate, the ozone reduction in percent and the accumulative ozone loss are the magnitudes used to assess the ozone depletion every year. Figure 4 illustrates the ozone loss rate for the total column during phase II (days 220-273) (right scale) and the ozone loss with respect to the August value in percent (left scale). The total amount of ozone depleted is displayed at the top of the bars. Ozone loss rates were calculated from the total integrated ozone column obtained from each sonde, as explained in Sect. 3.2. Only when the sonde reaches altitudes over $17 \mathrm{hPa}$ is integration reliable (Claude et al., 1987). In 2009 not enough sondes fulfilled the mentioned condition to evaluate ozone loss in total column. The decrease of the total ozone column over Belgrano during spring varies from 20 to $59 \%$, depending on the year. The largest ozone loss of 140-160 DU (55-60\%) was observed in the coldest years (2000, 2003 and 2006), while the lowest loss of ozone,
57 DU (20\%), occurred in 2002 due to the unprecedented major warming over the Southern Hemisphere in spring and the vortex splitting into two centres (Charlton et al., 2005; Hoppel et al., 2003; Newman and Nash, 2005; Roscoe et al., 2005). Other warm winters such as those of 2004 and 2010 exhibited a lower ozone loss of $123 \mathrm{DU}(46 \%)$ and $77 \mathrm{DU}$ $(33.7 \%)$, respectively. The magnitudes found are in agreement with the previous work of Kuttippurath et al. (2010).

When dividing the atmosphere into the three layers described above, details on inter-annual variability of the ozone loss rate can be better observed. Figure 5 shows ozone loss rates series in the three layers for the time window given in Sect. 3.1. Layers exhibit standard deviations ranging from 0.14 to $0.30 \mathrm{DU} \mathrm{day}^{-1}$, the largest being in layer II. However this magnitude cannot be compared between layers as the mean values associated are quite different. When relative variability is considered, the coefficient of relative variation is largest in layer III (83.4\%) and is explained mainly by the contribution of the 2002 event. When the anomalous year 2002 is not taken into account, this coefficient is reduced in all layers, as expected. In layer III, the relative variability is less than half of the previous value $(41 \%)$, while in the layers II and I, the coefficient is reduced by 15 and $20 \%$, respectively. This fact indicates a higher contribution from the 2002 event in layer III. On the other hand, the largest relative variability in layer III when 2002 is not included might be related to greater temperature variations at higher altitudes resulting from stratospheric minor warmings that occurred in 2004 and 2010 (de Laat and van Weele, 2011). In fact, when these two years are excluded, relative variability in layer III is reduced to $19 \%$ and shows similar values to those in in layers II and I.

The main observed feature is a reduction of the ozone loss rate in 2002, reaching values below two standard deviations. The anomalous behaviour of the atmosphere in that year was a consequence of the already mentioned vortex splitting. As a result, stratospheric temperature rose quickly inside the vortex. Over Belgrano, a dramatic temperature increase of $54^{\circ} \mathrm{C}$ at the isentropic level of $700 \mathrm{hPa}$ was observed by two consecutive soundings separated by one week. The ozone depletion process was suddenly stopped and a fast poleward transport of ozone-enriched mid-latitude air arrived at the station at all levels above $550 \mathrm{~K}$, affecting also the levels below that height (Yela et al., 2005).

In the year 2010 the ozone loss rate is the second lowest of the data series and in the top layer it is even negative. A negative ozone loss rate indicates an increase in ozone during the period considered. However this case cannot be interpreted as the ozone destruction not taking place but rather as the ozone depletion finishing earlier than the time window considered. This fact is related to a minor sudden stratospheric warming (SSW) in July covering the polar region, resulting in an increase in temperature of $20^{\circ} \mathrm{C}$ in less than two weeks leading to the evaporation of PSC and a deactivation of halogen species. Areas of potential PSC-I (NAT) presence 


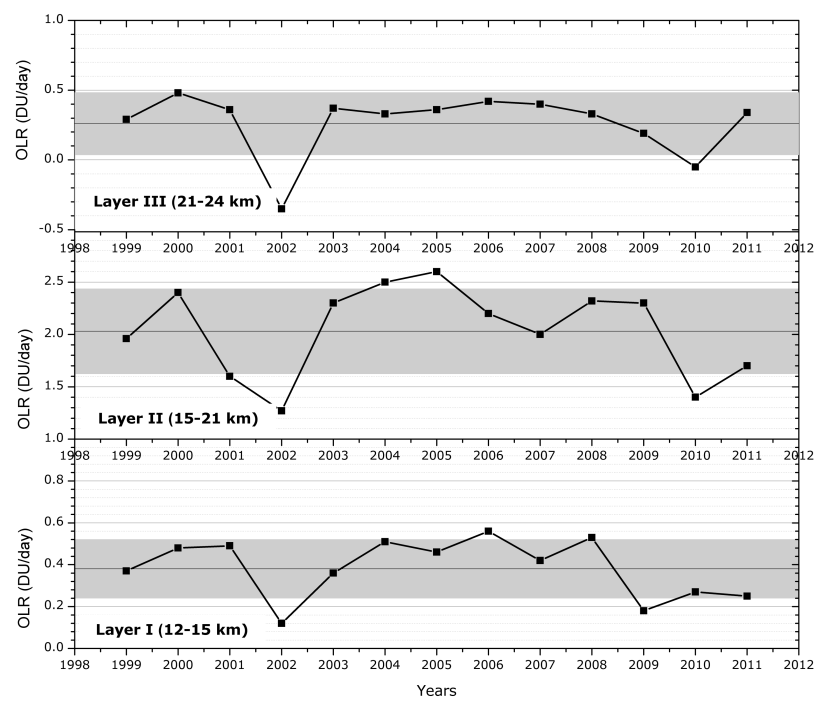

Fig. 5. Inter-annual evolution of the ozone loss rate in the layer III 21-24 km layer (upper plot), in layer II (middle plot) and in layer I (lower plot) during phase II (days 220-273). Grey shaded areas indicate one standard deviation.

have been calculated for 2010 assuming values of $5 \mathrm{ppmv}$ $\mathrm{H}_{2} \mathrm{O}$ and 9-10 ppbv $\mathrm{HNO}_{3}$ (Müller et al., 2001) (Fig. 6). In 2010, after the mentioned minor warming, the area of potential presence of PSC I was $20 \%$ lower than the mean values for the period 1999-2011. The total integrated area in 2010 was $9 \%$ lower than the mean area. Less PSCs result in less halogen activation and hence less $\mathrm{O}_{3}$ depletion. In addition, de Laat and van Weele (2011) found, using Microwave Limb Sounder (MLS) data, an enrichment of water vapour in the $10-50 \mathrm{hPa}$ layer which strongly modified the chemical composition of the region and inhibited the ozone destruction process.

Year-to-year ozone loss rates are influenced by a number of factors which are not independent of each other: activated halogen compounds present when sunlight arrives, winter temperature and the amount of ozone present when depletion starts. In Fig. 7 ozone loss rates are plotted against the amount of ozone partial column by the time when direct depletion takes place to show that the amount of "initial" ozone plays a role in determining the individual year ozone loss rate. For a reference, the integrated ozone amount of $1 \mathrm{Au}-$ gust was used as initial ozone. In years when no data were available for that day, an interpolation from closest sounding was performed. When the anomalous year 2002 is excluded from the analysis, the correlation coefficient is 0.69 , indicating an ozone loss rate dependence on the initial ozone. The same result was found in a previous study for SPS (Hofmann et al., 2009). Winter ozone is determined by dynamics through planetary wave forcing of the mean meridional circulation. This relation has been quantified by the correlation between the Eliassen-Palm (EP) flux anomalies entering the

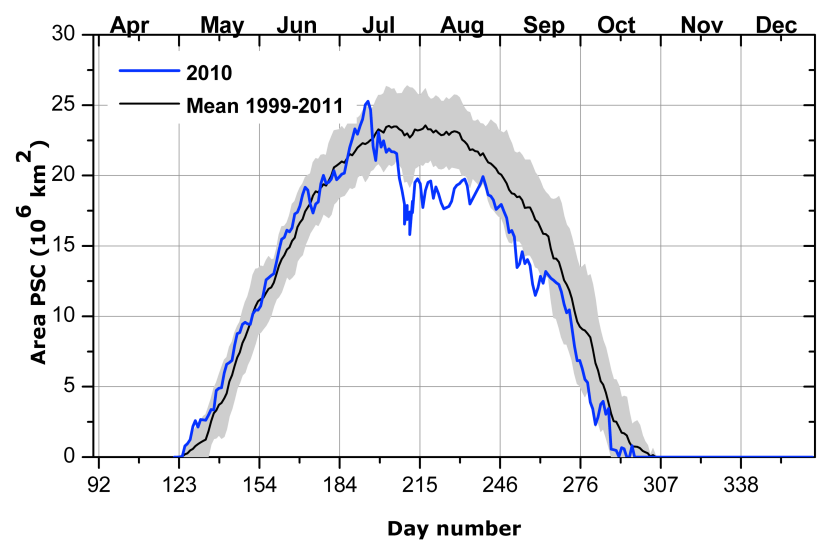

Fig. 6. Mean area of potential polar stratospheric clouds (PSC-I) formation based on ECMWF operational analysis truncated to T106 horizontal resolution $\left(1.125^{\circ} \times 1.125^{\circ}\right)$ for the period $1999-2011$ (black line). The grey area represents one standard deviation. The area for the year 2010 is shown in blue line.

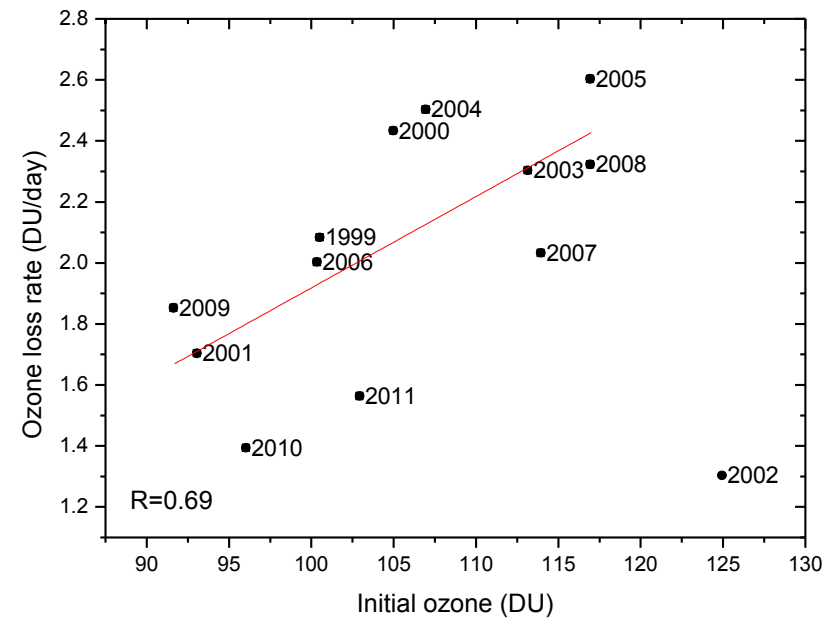

Fig. 7. Ozone loss rate versus the amount of ozone present before the direct ozone depletion starts (1 August) for all years of measurements. The correlation coefficient shown was obtained without inclusion of the anomalous year 2002 .

lower stratosphere and the ozone anomalies at high latitudes of Southern Hemisphere (Salby et al., 2011). The high correlation means that years with greater poleward transport are related to a positive anomaly in ozone (Weber et al., 2011). In these years larger amounts of reservoirs $\left(\mathrm{HCl}\right.$ and $\left.\mathrm{ClONO}_{2}\right)$ reach the polar stratosphere. In spring, these molecules are converted into active radicals, leading to a higher ozone loss rate compared to years of lesser meridional transport.

The stratospheric temperature and the strength of polar vortex, which are strongly related to the planetary wave activity, play major roles in the amount of ozone and the rate of depletion. A strong correlation between ozone loss and volume of PSCs $(r=0.9)$ has been found in the Arctic (Rex 


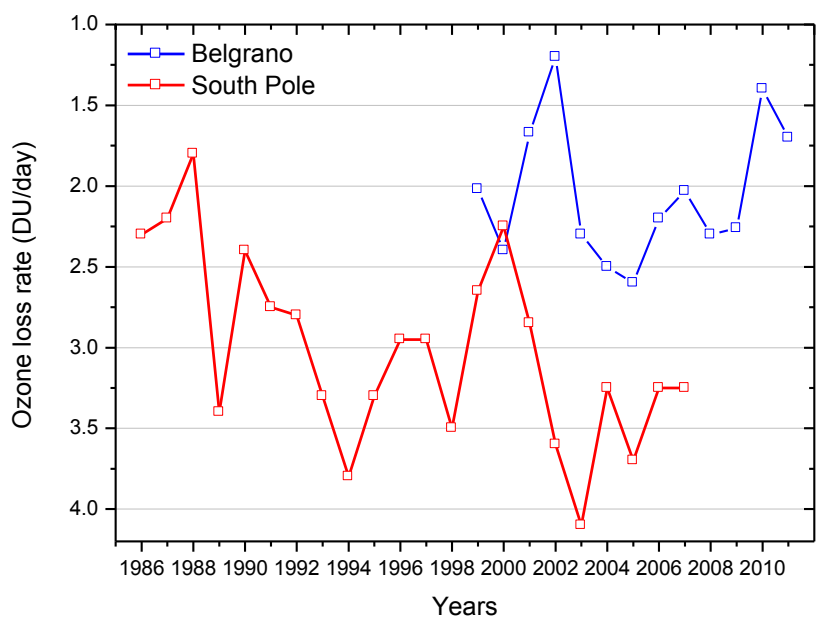

Fig. 8. Time series of ozone loss rate at Belgrano (blue line) and at South Pole (red line) stations.

et al., 2004, 2006; Harris et al., 2010). In Antarctica, the inter-annual variability based on the correlation is meaningless since PSC occurrence reaches the saturation level inside the vortex (Yang et al., 2008). In many years the ozone loss rate is very similar (see years 1999, 2000, 2003, 2004, 2005 and 2006). Only in warm years is there a reduction in ozone loss rate, which becomes apparent in 2010 and in the extreme case of 2002 mentioned above.

Recent studies based on longer time series have compared ozone loss rates in different periods finding a change in the trend for periods before and after 1996. For instance, Yang et al. (2008) found a decline in the rate of ozone loss since 1997, statistically significant at the $95 \%$ confidence level, and conclude that the reduced amount of halogen over the past decade has contributed to the first stage of ozone recovery in the Antarctic region. Positive ozone trends were also reported by Austin et al. (2010) and Kiesewetter et al. (2010) during the period 2000-2009 using a chemistry transport model; however they attributed this fact mainly to changes in meteorology, as the reduction in stratospheric halogen loading is still small in this period. Recently, Kuttippurath et al. (2013) analysed ozone data from satellite and groundbased instruments for the period 1989-2010 in the Antarctic vortex. Their results have revealed a first sign of ozone recovery in the Antarctic vortex.

\subsection{Ozone distribution within the vortex: Belgrano vs. South Pole}

Ozone loss rates from Belgrano have been compared with those obtained for SPS (Hofmann et al., 2009) in order to examine the vortex spatial homogeneity. Calculations have been carried out for the month of September to make data directly comparable. Results (Fig. 8) show a higher ozone loss rates at SPS by as much as $25 \%$ for the 1999-2007 overlap- ping period. Such a large difference in ozone loss rate between two stations located clearly inside the Antarctic vortex was not an expected result. In order to find where the origin of such differences is, we have compared the evolution of stratospheric temperatures in both stations. The period of stratospheric temperatures low enough for PSC formation over SPS starts a few days earlier than that at Belgrano and ends at the same time. The difference in time between the two stations is not significant compared to the overall period of potential PSCs over both stations, from the end of May to beginning of October (about 16-17 weeks) (not shown). Therefore, the temperature differences between both stations cannot explain the differences in ozone loss rates found. Figure 9 displays the mean value of the ozone partial column in layer II but with the SPS data included. In both stations, a slow decline of ozone is observed before the sunlight reaches the stations, delayed about 10-12 days at SPS. As we have mentioned before, this ozone reduction is caused by transport of ozone-depleted air from lower latitudes where the ozone depletion had already started. The delay observed on SPS is a result of the time the ozone-poor air takes to travel from 78 to $90^{\circ} \mathrm{S}$ according to Lee et al. (2001). These observational results are in excellent agreement with the evolution of losses versus latitude and time computed by the SLIMCAT 3-D chemical-transport model for the year 1996 and $480 \mathrm{~K}$ isentropic level (Lee et al., 2001). Moreover, the model also shows that accumulated ozone loss becomes equal at a equivalent latitude poleward of $74^{\circ} \mathrm{S}$ by the beginning of October, as found in the observations.

Sunrise at a height of $18 \mathrm{~km}$ over Belgrano coincides with the change in the slope of the ozone loss rate toward larger values, starting the phase II, where ozone loss rate is almost linear. As long as the sunlight returns to the deep vortex, ozone depletion accelerates by chemical reactions. Therefore, the ozone reduction by mixing of air with less ozone content at SPS gets faster. At SPS, sunlight reaches the station 32 days later than in Belgrano. At this time, ozone has already been reduced by almost half that of the pre-ozone-hole conditions. Accumulated solar radiation during the first four weeks after sunrise in both stations is quite different. In Belgrano it is about $200 \mathrm{~h}$, while at SPS it is $668 \mathrm{~h}$. Greater rates of accumulated light could lead to activation of more halogen compounds at SPS. Santee et al. (2008) found a positive chlorine gradient toward the pole for this season by analysing AURA-MLS data. Therefore, more activated chlorine at SPS could be responsible of the higher ozone loss rate. As a consequence of the greater SPS ozone loss rates, the complete destruction takes place simultaneously at both stations by the beginning of October.

Other previous works have also compared ozone evolution during the ozone hole period at different stations (Kuttippurath et al., 2010, 2013). The results of these studies conclude that the severity of the ozone loss is related to the position of the station with respect to the polar vortex, being more severe at locations well inside the polar vortex like Belgrano and 


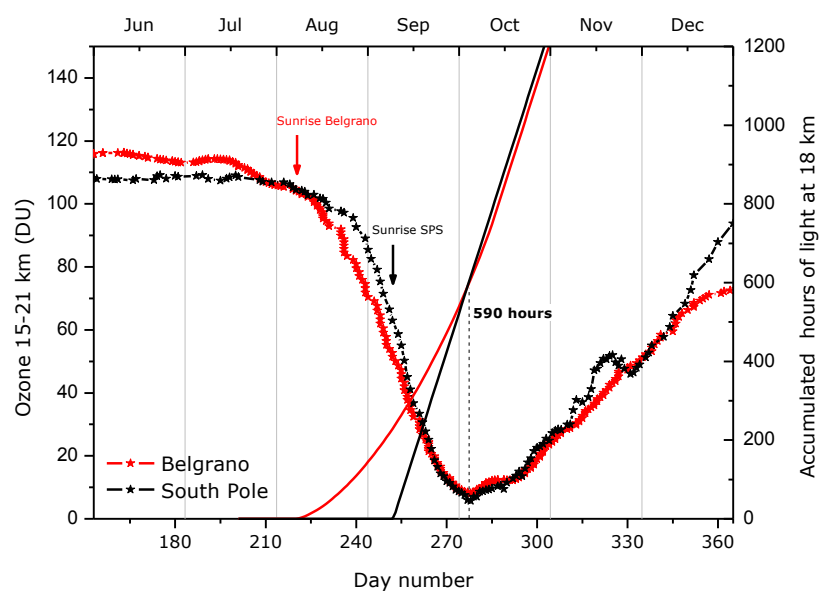

Fig. 9. Mean values from years 1999-2009 of the ozone partial column for the 15-21 km layer (left scale) for Belgrano (red stars) and SPS (black stars). Solid lines represent the accumulated hours of light for both stations (same colour code, scale at the right side).

SPS than at the edge of the vortex. However, they did not find differences between Belgrano and SPS, whereas we found differences in the behaviour of the ozone evolution in two stations well inside the polar vortex. Ozone loss rates between these stations confirm the results of transport in the Antarctic polar vortex through a 3-D chemical-transport model (Lee et al., 2001).

\subsection{Ozone variability in November and December}

The top panel in Fig. 10 displays the integrated total ozone column from $12-24 \mathrm{~km}$ (the three layers considered) in November and December. A great interannual variability is observed, especially in November, with values ranging from 60 to 220 DU. During the last few years, extremely low ozone values were observed until the end of the year. As already mentioned, in November the ozone budget is dominated by the ozone eddy transport, this contribution being about $80 \%$ of the total ozone transport (Miyazaki et al., 2005). Taking into account that the strength of the eddy transport is strongly dependent on wave activity, on the strength of the polar vortex and on the presence of a strong meridional ozone gradient (Monier and Weare, 2011), a relationship between the persistence of low ozone content during November and December in the lower stratosphere and the behaviour of the polar vortex is expected. One of the parameters that is useful for assessing the strength of the polar vortex is the gradient of potential vorticity (Steinhorst et al., 2005). The middle panels in Fig. 10 show the monthly meridional gradient of potential vorticity at the isentropic level of $475 \mathrm{~K}$ averaged for all longitudes in November and December. Results show an increase in the vortex strength during the last decade. These high values indicate that the transport across the vortex is weak and can explain the low ozone values registered dur-

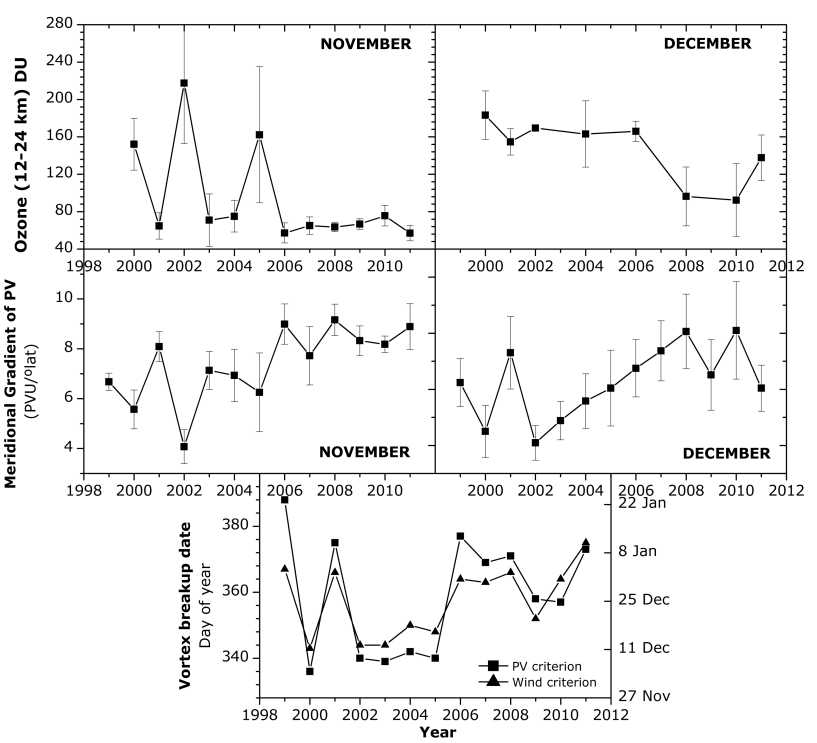

Fig. 10. Top panels show integrated ozone column in the layer 12$24 \mathrm{~km}$ in November and December. The vertical error bars indicate one standard deviation. Middle panels show the mean meridional gradient $\left(60-90^{\circ} \mathrm{S}\right)$ of potential vorticity at the isentropic level of $475 \mathrm{~K}$. The lowest panel presents the day of the final breakdown of the Antarctic polar vortex from 1999 to 2011 based on Black et al. (2006) (squares) and Waugh et al. (1999) (triangles) definitions.

ing the last years. On the other hand, a weaker vortex brings about more exchange of air masses with high ozone from outside of the vortex, leading to the ozone build-up. Moreover, a strong vortex persisting until November and December is a signal of a late polar vortex breakdown. The bottom panel shows the date of breakdown of the Southern Hemisphere polar vortex calculated using the criteria defined in Sect. 3.3. The day of the breakdown varies from early December to mid-January. It can be observed that in the last years of when the polar vortex was stronger, the final breakdown takes place later than for years with a weaker one. Some studies have been done to analyse the potential factors contributing to the evolution of the Antarctic polar vortex and were in particular focused on the delay in its breakdown (Haigh and Roscoe, 2009; Fogt et al., 2009; Perlwitz et al., 2008; Gillett and Thompson, 2003). Their results have demonstrated that ozone depletion is a major factor influencing the delay in the polar vortex breakup, while the combined effects of solar activity, the phase of the quasi-biennial oscillation and greenhouse gases exert only a small influence. Thus, all of them play an important role in the rate of the ozone recovery.

\section{Summary and conclusions}

An ozone and temperature climatology have been constructed based on $13 \mathrm{yr}$ of ozonesonde data over the time 
period 1999-2011 at Belgrano station in Antarctica. The seasonal ozone maximum takes place in January at an altitude of $20 \mathrm{~km}$. Subsequently, the height of the maximum descends at a rate of $22 \mathrm{~m} \mathrm{day}^{-1}$ from February to May. Meteorological conditions for halogen activation are present from May to late October. In this period, stratospheric temperatures below the threshold for PSC-I cover a deep stratospheric layer from 15 to $30 \mathrm{~km}$. The minimum temperature occurs near the end of July at $21 \mathrm{~km}$. As spring proceeds, heating at upper levels propagates downwards, closely coinciding with ozone increase at a mean rate of about $0.5^{\circ} \mathrm{Cday}^{-1}$.

Total ozone depletion during spring varies from 20 to $59 \%$ of August values, depending on the year. The largest ozone losses were of about 140-160 DU in the coldest years, while the lowest value of $57 \mathrm{DU}(20 \%)$ occurred in 2002 due to the unprecedented major warming over the Southern Hemisphere.

An in-depth analysis of ozone variability was performed in three stratospheric layers in which ozone suffers chemical depletion. It has been observed that an $11 \%$ reduction of the ozone partial column in the most severely affected layer (15$21 \mathrm{~km})$ takes place when Belgrano is still in darkness, and is attributed to dilution effects with air from a somewhat lower latitude near the edge of the polar vortex, where ozone depletion has already started. When sunlight reaches the station, an almost linear mean ozone loss rate of $-2.0 \mathrm{DU} \mathrm{day}^{-1}$ is found. By comparison with SPS it was found that the ozone loss rate was over $25 \%$ higher than at Belgrano and the ozone minimum was reached simultaneously around day 275 (2 October), when the lower stratosphere above both stations received the same amount of light, around $600 \mathrm{~h}$. These results of the ozone behaviour in two stations within the polar vortex provide experimental support for the previous modelling studies on transport of ozone-depleted air from the edge to the core (Lee et al., 2001). The ozone behaviour during the ozone hole period at the two stations is explained by considering the effect of the transport of air masses from a somewhat lower latitude near the edge of the polar vortex, where ozone loss has already started, and the accumulated hours of sunlight, which are greater at the South Pole after the spring equinox.

Finally, the analysis of the rate of the ozone hole buildup in November and December shows a clear relationship between the persistence of low ozone content during this period, the strength of the polar vortex and the timing of its final breakdown.

Acknowledgements. We thank the different ozone sounding operational teams at Belgrano station. We also would like to thank to ECMWF for providing potential vorticity and temperature data. This work has been partially funded by Spanish Polar Program (CICYT-ANT97-0433, REN2000-0245-C02-01, CGL2004-05419C02-01/ANT, POL2006-0382 and CGL2010-20353) and EU 5th Framework Programme (QUOBI project, EVK2-2001-00129).
Edited by: T. J. Dunkerton

\section{References}

Arblaster J. M. and Meehl, G. A.: Contributions of external forcings to Southern Annual Mode Trends, J. Climate, 19, 2896-2905, 2006.

Austin, J., Struthers, H., Scinocca, J., Plummer, D. A., Akiyoshi, H., Baumgaertner, A. J. G., Bekki, S., Bodeker, G. E., Braesicke, P., Brühl, C., Butchart, N., Chipperfield, M. P., Cugnet, D., Dameris, M., Dhomse, S., Frith, S., Garny, H., Gettelman, A., Hardiman, S. C., Jöckel, P., Kinnison, D., Kubin, A., Lamarque, J. F., Langematz, U., Mancini, E., Marchand, M., Michou, M., Morgenstern, O., Nakamura, T., Nielsen, J. E., Pitari, G., Pyle, J., Rozanov, E., Shepherd, T. G., Shibata, K., Smale, D., Teyssèdre, H., and Yamashita, Y.: Chemistry-climate model simulations of spring Antarctic ozone, J. Geophys. Res., 115, D00M11, doi:10.1029/2009JD013577, 2010.

Black, R. X. and McDaniel, B. A.: Interannual Variability in the Southern Hemisphere Circulation Organized by Stratospheric Final Warming Event, J. Atmos. Sci., 64, 2968-2974, 2007.

Bodeker, G. E., Shiona, H., and Eskes, H.: Indicators of Antarctic ozone depletion, Atmos. Chem. Phys., 5, 2603-2615, doi:10.5194/acp-5-2603-2005, 2005.

Charlton, A. J., O'Neill, A., Lahoz, W. A., and Berrisford, P.: The Splitting of the Stratospheric Polar Vortex in the Southern Hemisphere, September 2002: Dynamical Evolution, J. Atmos. Sci., 62, 590-602, 2005.

Christensen, T., Knudsen, B. M., Streibel, M., Andersen, S. B., Benesova, A., Braathen, G., Claude, H., Davies, J., De Backer, H., Dier, H., Dorokhov, V., Gerding, M., Gil, M., Henchoz, B., Kelder, H., Kivi, R., Kyrö, E., Litynska, Z., Moore, D., Peters, G., Skrivankova, P., Stübi, R., Turunen, T., Vaughan, G., Viatte, P., Vik, A. F., von der Gathen, P., and Zaitcev, I.: Vortex-averaged Arctic ozone depletion in the winter 2002/2003, Atmos. Chem. Phys., 5, 131-138, doi:10.5194/acp-5-131-2005, 2005.

Claude, H., Hartmannsgruber, R., and Köhler, U.: Measurment of atmospheric ozone profiles using the Brewer/Mast sonde, WMO Global Ozone Research and Monitoring Project, Report No. 17, WMO/TD, No. 179, 1987.

Cordero, E. C. and Kawa, S. R.: Ozone and tracer transport variations in the summer Northern Hemisphere stratosphere, J. Geophys. Res., 106, 12227-12239, doi:10.1029/2001JD900004, 2001.

Crutzen, P. J. and Brühl, C.: Catalysis by $\mathrm{NO}_{\mathrm{x}}$ as the Main Cause of the Spring to Fall Stratospheric Ozone Decline in the Northern Hemisphere, J. Phys. Chem., 105, 1579-1582, 2001.

de Laat, A. T. J. and van Weele, M.: The 2010 Antarctic ozone hole: Observed reduction in ozone destruction by minor sudden stratospheric warmings, Sci. Rep., 1, 38, doi:10.1038/srep00038, 2011.

Deshler, T., Mercer, J. L., Smit, H. G. J., Stubi, R., Levrat, G., Johnson, B. J., Oltmans, S., Kivi, R., Thompson, A. M., Witte, J., Davies, J., Schmidlin, F. J., Brothers, G., and Sasaki, T.: Atmospheric comparison of electrochemical cell ozonesondes from different manufacturers, and with different cathode solution strengths: The Balloon Experiment on 
Standards for Ozonesondes, J. Geophys. Res., 113, D04307, doi:10.1029/2007JD008975, 2008.

EN-SCI Corporation, Instruction Manual, Model 1Z ECC-O3Sondes, Boulder, Colorado, 1996.

Eyring, V., Cionni, I., Bodeker, G. E., Charlton-Perez, A. J., Kinnison, D. E., Scinocca, J. F., Waugh, D. W., Akiyoshi, H., Bekki, S., Chipperfield, M. P., Dameris, M., Dhomse, S., Frith, S. M., Garny, H., Gettelman, A., Kubin, A., Langematz, U., Mancini, E., Marchand, M., Nakamura, T., Oman, L. D., Pawson, S., Pitari, G., Plummer, D. A., Rozanov, E., Shepherd, T. G., Shibata, K., Tian, W., Braesicke, P., Hardiman, S. C., Lamarque, J. F., Morgenstern, O., Pyle, J. A., Smale, D., and Yamashita, Y.: Multimodel assessment of stratospheric ozone return dates and ozone recovery in CCMVal-2 models, Atmos. Chem. Phys., 10, 94519472, doi:10.5194/acp-10-9451-2010, 2010.

Fahey, D. W. and Ravishankara, A. R.: Summer in the stratosphere, Science, 285, 208-210, 1999.

Farman, J. C., Gardiner, B. G., and Shanklin J. D.: Large losses of total ozone in Antarctica reveal seasonal $\mathrm{ClO}_{\mathrm{X}} / \mathrm{NO}_{\mathrm{X}}$ interactions, Nature, 315, 207-210, 1985.

Fogt, R. L., Perlwitz, J., Pawson, S., and Olsen M. A.: Intra-annual relationships between polar ozone and the SAM, Geophys. Res. Lett., 35, L04707, doi:10.1029/2008GL036627, 2009.

Frederick, J. E. and Alberts, A. D.: Prolonged enhancement in surface ultraviolet radiation during the Antarctic spring of 1990, Geophys. Res. Lett., 8, 1869-1871, 1991.

Gillett, N. and Thompson, D. W. J.: Simulation of recent Southern Hemisphere climate change, Science, 302, 273-275, 2003.

Haigh, J. D. and Roscoe, H. K.: The final warming date of the Antarctic polar vortex and influences on its interannual variability, J. Climate, 22, 5809-5819, 2009.

Hanson, D. and Mauersberger, K.: Solubility and equilibrium vaporpressures of $\mathrm{HCl}$ Dissolved in Polar Stratospheric Cloud Materials - Ice and the Trihydrate of Nitric-Acid, Geophys. Res. Lett., 15, 1507-1510, 1988.

Harris, N. R. P., Lehmann, R., Rex, M., and von der Gathen, P.: A closer look at Arctic ozone loss and polar stratospheric clouds, Atmos. Chem. Phys., 10, 8499-8510, doi:10.5194/acp-10-84992010, 2010.

Hassler, B., Daniel, J. S., Johnson, B. J., Solomon, S., and Oltmans, S. J.: An assessment of changing ozone loss rates at South Pole: twenty-five years of ozonesonde measurements, J. Geophys. Res., 116, D22301, doi:10.1029/2011JD016353, 2011.

Hofmann, D. J., Johnson, B. J., and Oltmans, S. J.: Twenty two years of ozonesonde measurements at the South Pole, Int. J. Remote Sens., 30, 3995-4008, doi:10.1080/01431160902821932, 2009.

Hoppel, K., Bevilacqua, R., Allen, D., Nedoluha, G., and Randall, C.: POAM III observations of the anomalous 2002 Antarctic ozone hole, Geophys. Res. Lett., 30, 1394, doi:10.1029/2003GL016899, 2003.

Huck, P. E., Tilmes, S., Bodeker, G. E., Randel, W. J., McDonald, A. J., and Nakajima, H.: An improved measure of ozone depletion in the Antarctic stratosphere, J. Geophys. Res., 112, D11104, doi:10.1029/2006JD007860, 2007.

Kiesewetter, G., Sinnhuber, B.-M., Weber, M., and Burrows, J. P.: Attribution of stratospheric ozone trends to chemistry and transport: a modelling study, Atmos. Chem. Phys., 10, 12073-12089, doi:10.5194/acp-10-12073-2010, 2010.
Komhyr, W. D.: Operations handbook Ozone measurements to 40$\mathrm{km}$ altitude with model 4A electrochemical concentration cell (ECC) ozonesondes (used with $1680 \mathrm{MHz}$ radiosondes), NOAA Tech. Memo. ERL ARL-149, 49 pp., Air Resour. Lab., Boulder, Colorado, 1986.

Komhyr, W. D., Barnes, R. A., Brothers, G. B., Lathrop, J. A., and Opperman, D. P.: Electrochemical concentration cell ozonesonde performance evaluation during STOIC 1989, J. Geophys. Res., 100, 9231-9244, 1995.

Kravchenko, V. O., Evtushevsky, O. M., Grytsai, A. V., Klekociuk, A. R., Milinevsky, G. P., and Grytsai, Z. I.: Quasi-stationary planetary waves in late winter Antarctic stratosphere temperature as a possible indicator of spring total ozone, Atmos. Chem. Phys., 12, 2865-2879, doi:10.5194/acp-12-2865-2012, 2012.

Kuttippurath, J., Goutail, F., Pommereau, J.-P., Lefèvre, F., Roscoe, H. K., Pazmiño, A., Feng, W., Chipperfield, M. P., and GodinBeekmann, S.: Estimation of Antarctic ozone loss from groundbased total column measurements, Atmos. Chem. Phys., 10, 6569-6581, doi:10.5194/acp-10-6569-2010, 2010.

Kuttippurath, J., Lefèvre, F., Pommereau, J.-P., Roscoe, H. K., Goutail, F., Pazmiño, A., and Shanklin, J. D.: Antarctic ozone loss in 1979-2010: first sign of ozone recovery, Atmos. Chem. Phys., 13, 1625-1635, doi:10.5194/acp-13-1625-2013, 2013.

Lee, A. M., Roscoe, H. K., and Oltmans S.: Model and measurements show Antarctic ozone loss follows edge of polar night, Geophys. Res. Lett., 27, 3845-3848, doi:10.1029/2000GL011441, 2000.

Lee, A. M., Roscoe, H. K., Jones, A. E., Haynes, P. H., Shuckburgh, E. F., Morrey, M. W., and Pumphrey, H. C.: The impact of the mixing properties within the Antarctic stratospheric vortex on the ozone loss in spring, J. Geophys. Res., 106, 3203-3211, 2001.

Logan, J.: Trends in the vertical distribution of ozone: An analysis of ozonesonde data, J. Geophys. Res., 99, 25553-25585, 1994

Lubin, D. and Jensen, E. H.: Effects of clouds and stratospheric ozone depletion on ultraviolet radiation trends, Nature, 377, 710 713, 1995.

McKenzie, R. L., Matthews, W. A., and Johnston, P. V.: The relationship between erythemal UV and ozone, derived from spectral irradiance measurements, Geophys. Res. Lett., 18, 2269-2272, 1991.

Miyazaki, K., Iwasaki, T., Shibata, K., and Deush, M.: Role of transport in the seasonal variation of the total ozone content, J. Geophys. Res., 110, D18309, doi:10.1029/2005JD005900, 2005.

Monier, E. and Weare, B. C.: Climatology and trends in the forcing of the stratospheric zonal-mean flow, Atmos. Chem. Phys., 11, 12751-12771, doi:10.5194/acp-11-12751-2011, 2011.

Müller, M., Neuber, R., Beyerle, G., Kyrö, E., Kivi, R., and Wöste, L.: Non-uniform PSC occurrence within the Arctic polar vortex, Geophys. Res. Lett., 28, 4175-7178, 2001.

Nash, E. R., Newman, P. A., Rosenfield, J. E., and Schoeberl, M. R.: An objective determination of the polar vortex using Ertel's potential vorticity, J. Geophys. Res., 101, 9471-9478, 1996.

Newman, P. A. and Nash, E. R.: The unusual Southern Hemisphere stratosphere winter of 2002, J. Atmos. Sci., 62, 614-628, 2005.

Osterman, G. B., Salawitch, R. J., Sen, B., Toon, G. C., Stachnik, R. A., Pickett, H. M., Margitan, J. J., Blavier, J., and Peterson, D. B.: Balloon-borne measurements of stratospheric radicals and their precursors: Implications for the production and loss of ozone, Geophys. Res. Lett., 24, 1107-1110, 1997. 
Parrondo, M. C., Yela, M., Gil, M., von der Gathen, P., and Ochoa, H.: Mid-winter lower stratosphere temperatures in the Antarctic vortex: comparison between observations and ECMWF and NCEP operational models, Atmos. Chem. Phys., 7, 435-441, doi:10.5194/acp-7-435-2007, 2007.

Perlwitz, J., Pawson, S., Fogt, R. L., Nielsen, J. E., and Neff, W. D.: Impact of stratospheric ozone hole recovery on Antarctic climate, Geophys. Res. Lett., 35, L08714, doi:10.1029/2008GL033317, 2008.

Rex, M., Salawitch, R., von der Gathen, P., Harris, N., Chipperfield, M., and Naujokat, B.: Arctic ozone loss and climate change, Geophys. Res. Lett., 31, L04116, doi:10.1029/2003GL018844, 2004.

Rex, M., Salawitch, R. J., Deckelmann, H., von der Gathen, P., Harris, N. R. P., Chipperfield, M. P., Naujokat, B., Reimer, E., Allaart, M., Andersen, S. B., Bevilacqua, R., Braathen, G. O., Claude, H., Davies, J., De Backer, H., Dier, H., Dorokov, V., Fast, H., Gerding, M., Godin-Beekmann, S., Hoppel, K., Johnson, B., Kyrö, E., Litynska, Z., Moore, D., Nakane, H., Parrondo, M. C., Risley, A. D., Skrivankova, P., Stübi, R., Viatte, P., Yushkov, V., and Zerefos, C.: Arctic winter 2005: Implications for stratospheric ozone loss and climate change, Geophys. Res. Lett., 33, L23808, doi:10.1029/2006GL026731, 2006.

Roscoe, H. K., Jones, A. E., and Lee, A. M.: Midwinter start to Antarctic ozone depletion: Evidence from observations and models, Science, 278, 93-96, 1997.

Roscoe, H. K., Shanklin, J. D., and Colwell, S. R.: Has the Antarctic vortex split before 2002?, J. Atmos. Sci., 62, 581-588, 2005.

Roscoe, H. K., Feng, W., Chipperfield, M. P., Trainic, M., and Shuckburgh, E. F.: The existence of the edge region of the Antarctic stratospheric vortex, J. Geophys. Res., 117, D04301, doi:10.1029/2011JD015940, 2012.

Rosenfield, J. E., Newman, P. A., and Schoeberl, M. R.: Computations of diabatic descent in the stratospheric polar vortex, Computations of diabatic descent in the stratospheric polar vortex, J. Geophys. Res., 99, 16677-16689, 1994.

Salby, M., Titova, E., and Deschamps, L.: Rebound of Antarctic ozone, Geophys. Res. Lett., 38, L09702, doi:10.1029/2011GL047266, 2011.

Salby, M., Titova, E. A., and Deschamps, L.: Changes of the Antarctic ozone hole: Controlling mechanisms, seasonal predictability, and evolution, J. Geophys. Res., 117, D10111, doi:10.1029/2011JD016285, 2012.

Santee, M. L., Lambert, A., Read, W. G., Livesey, N. J., Manney, G. L., Cofield, R. E., Cuddy, D. T., Daffer, W. H., Drouin, B. J., Froidevaux, L., Fuller, R .A., Jarnot, R. F., Knosp, B. W., Perun, V. S., Snyder, W. V., Stek, P. C., Thurstans, R. P., Wagner, P. A., Waters, J. W., Connor, B., Urban, J., Murtagh, D., Ricaud, P., Barrett, B., Kleinböhl, A., Kuttippurath, J., Küllmann, H., von Hobe, M., Toon, G. C., and Stachnik, R. A.: Validation of the Aura Microwave Limb Sounder ClO measurements, J. Geophys. Res., 113, D15S22, doi:10.1029/2007JD008762, 2008.

Santer, B. D, Wehner, M. F, Wigley, T. M. L, Sausen, R., Meehl, G. A., Taylor, K. E., Ammann, C., Arblaster, J., Washington, W. M., Boyle, J. S., and Brüggemann, W.: Contributions of anthropogenic and natural forcing to recent tropopause height changes, Science, 301, 479-483, 2003.

Sato, K., Tomikawa, Y., Hashida, G., Yamanouchi, T., Nakajima, H., and Sugita, T.: Longitudinally dependent ozone increase in the Antarctic polar vortex revealed by balloon and satellite observations, J. Atmos. Sci., 66, 1807-1820, doi:10.1175/2008JAS2904.1, 2009.

Smit, H. G. J., Straeter, W., Johnson, B. J., Oltmans, S. J., Davies, J., Tarasick, D. W., Hoegger, B., Stubi, R., Schmidlin, F. J., Northam, T., Thompson, A. M., Witte, J. C., Boyd, I., and Posny, F.: Assessment of the performance of ECC ozone sondes under quasiflight conditions in the environmental simulation chamber: Insights from the Juelich Ozone Sonde Intercomparison Experiment (JOSIE), J. Geophys. Res., 112, D19306, doi:10.1029/2006JD007308, 2007.

Solomon, S., Portmann, R. W., Sasaki, T., Hofmann, D. J., and Thompson, D. W. J.: Four decades of ozonesonde measurements over Antarctica, J. Geophys. Res., 110, D21311, doi:10.1029/2005JD005917, 2005.

Son, S. W., Tandon, N. F., Polvani, L. M., and Waugh, D. W.: Ozone hole and southern hemisphere climate change, Geophys. Res. Lett., 36, L15705, doi:10.1029/2009GL038671, 2009.

Sonkaew, T., von Savigny, C., Eichmann, K.-U., Weber, M., Rozanov, A., Bovensmann, H., Burrows, J. P., and Grooß, J.-U.: Chemical ozone losses in Arctic and Antarctic polar winter/spring season derived from SCIAMACHY limb measurements 2002-2009, Atmos. Chem. Phys., 13, 1809-1835, doi:10.5194/acp-13-1809-2013, 2013.

Steinhorst, H. M., Konopka, P., Günther, G., and Müller, R.: How permeable is the edge of the Arctic vortex - Model studies of the winter 1999-2000, J. Geophys. Res., 110, D06105, doi:10.1029/2004JD005268, 2005.

Stolarski, R., Schoeberl, M., Newman, P., McPeters, R., and Krueger, A.: The 1989 Antarctic ozone hole as observed by TOMS, Geophys. Res. Lett., 17, 1267-1270, 1990.

Thompson, A. M., Oltmans, S. J., Schmidlin, F. J., Logan, J. A., Fujiwara, M., Kirchoff, V. W. J. H., Posny, F., Coetzee, G. J. R., Hoegger, B., Kawakami, S., Ogawa, T., Johnson, B. J., Vömel, H., and Labow, G.: The 1998-2000 SHADOZ (Southern Hemisphere Additional Ozonesondes) tropical ozone climatology. 1. Comparison with TOMS and groundbased measurements, J. Geophys. Res., 108, D28238, doi:10.1029/2001JD000967, 2003.

Thompson, D. W. J. and Solomon, S.: Interpretation of recent southern hemisphere climate change, Science, 296, 895-899, doi:10.1126/science.1069270, 2002.

Tilmes, S., Müller, R., Grooß, J. U., Nakajima, H., and Sasano, Y.: Development of tracer relations and chemical ozone loss during the setup phase of the polar vortex, J. Geophys. Res., 111, D24S90, doi:10.1029/2005JD006726, 2006.

Uchino, O., Bojkov, R., Balis, D. S., Akagi, K., Hayashi, M., and Kajihara, R.: Essential characteristics of the Antarctic-spring ozone decline: update to 1998, Geophys. Res. Lett., 26, 13771380, 1999.

Waugh, D. W., Randel, W. J., Pawson, S., Newman, P. A., and Nash, E. R.: Persistence of the Lower Stratospheric Polar Vortices, J. Geophys. Res, 104, 27191-27201, 1999.

Weatherhead, E. C. and Andersen S. B.: The search for signs of recovery of the ozone layer, Nature, 441, 39-45, doi:10.1038/nature04746, 2006.

Weber, M., Dikty, S., Burrows, J. P., Garny, H., Dameris, M., Kubin, A., Abalichin, J., and Langematz, U.: The Brewer-Dobson circulation and total ozone from seasonal to decadal time scales, Atmos. Chem. Phys., 11, 11221-11235, doi:10.5194/acp-1111221-2011, 2011. 
World Meteorological Organization (WMO): Scientific Assessment of Ozone Depletion: 1994, Global Ozone Research and Monitoring Project, Rep. 37, Geneva, Switzerland, 1995.

World Meteorological Organization (WMO): Scientific Assessment of Ozone Depletion: 2006, Global Ozone Research and Monitoring Project, Rep. 50, Geneva, Switzerland, 2007.

World Meteorological Organization (WMO): Scientific Assessment of Ozone Depletion: 2010, Global Ozone Research and Monitoring Project, Rep. 50, Report No. 52, Geneva, Switzerland, 2010.

World Meteorological Organization (WMO): Quality Assurance and Quality Control for Ozonesonde Measurements in GAW, Geneva, Switzerland, WMO Rep. 201, 2011.
Yang, E. S., Cunnold, D. M., Newchurch, M. J., Salawitch, R. J., McCormick, M. P., Russell III, J. M., Zawodny, J. M., and Oltmans, S. J.: First stage of Antarctic ozone recovery, J. Geophys. Res., 113, D20308, doi:10.1029/2007JD009675, 2008.

Yela, M., Parrondo, C., Gil, M., Rodriguez, S., Araujo, J., Ochoa, H., Deferrari, G., and Diaz, S.: The September 2002 Antarctic vortex major warming as observed by visible spectroscopy and ozone soundings, Int. J. Remote Sens., 26, 3361-3376, 2005. 